\title{
Plant growth and survival of five introduced and two native/naturalized perennial grass genotypes exposed to two defoliation managements in arid Argentina
}

\author{
Y. A. Torres*, C. A. Busso*, O. A. Montenegrof, L. Ithurrart*, H. D. Giorgetti†, \\ G. D. Rodríguez†, D. Bentivegnał, ${ }^{1}$ R. E. Brevedan*, O. A. Fernández*, M. M. Mujica§, \\ S. S. Baioniף, L. Entío§, M. Fiorettiף and G. Tucat $\ddagger$ \\ * Departamento de Agronomía and CERZOS (CONICET), Universidad Nacional del Sur, Bahia Blanca, \\ Argentina, †Chacra Experimental de Patagones, Ministerio de Asuntos Agrarios, Carmen de Patagones, \\ Argentina, $\neq$ CERZOS (CONICET), CCT, Bahía Blanca, Argentina, §Facultad de Ciencias Agrarias, Universidad \\ Nacional de La Plata, La Plata, Argentina, TDepartamento de Agronomía, Universidad Nacional del Sur, Bahia \\ Blanca, Argentina
}

\begin{abstract}
The field performance of the native Pappophorum vaginatum, the naturalized Eragrostis curvula and various cultivars of the introduced Achnatherum hymenoides and Leymus cinereus was evaluated as potential forage resources in rangelands of arid Argentina during the warm seasons of 2007/2008 and 2008/2009. Plants of these grass species, obtained from seeds, were transplanted to the field in 2006, when they were 1 year old. During the study years, there were two defoliation managements: plants of all study genotypes either remained undefoliated (controls) or were defoliated twice a year during spring at $5 \mathrm{~cm}$ stubble height. Despite tiller number being lower $(P<0.05)$ on defoliated than on undefoliated plants, and total leaf length per unit basal area being similar $(P>0.05)$ between defoliation managements by mid-spring, there were no differences $(P>0.05)$ in dry weight production between defoliated and undefoliated plants in all genotypes at the end of the second growing season. Plants of one or more of the introduced genotypes showed a similar $(P>0.05)$ or greater $(P<0.05)$, but not lower, tiller number per plant and per square centimetre, daughter tiller production, total leaf length
\end{abstract}

Correspondence to: C. A. Busso, Departamento de Agronomía and CERZOS (CONICET), Universidad Nacional del Sur, San Andrés 800, (8000) Bahia Blanca, Argentina. E-mail: cebusso@criba.edu.ar

${ }^{1}$ Ex aequo from this author onward.

Received 26 July 2012; revised 18 April 2013 and dry weight production per unit basal area than the native species at the end of the first and/or second growing seasons. These morphological variables were similar $(P>0.05)$ or greater $(P<0.05)$ in the native than in the naturalized genotype. Plant survival, however, was lower $(P<0 \cdot 05$, overall mean $=20 \%)$ in the introduced than in the native $(>70 \%)$ or naturalized $(>39 \%)$ genotypes at the end of the first or second growing seasons.

Keywords: Achnatherum hymenoides, Eragrostis curvula, Leymus cinereus, Pappophorum vaginatum, plant demography, plant growth

\section{Introduction}

The cattle production industry in $75 \%$ of continental Argentina, characterized by arid and semi-arid areas, is based upon grazing of native vegetation (Fernández and Busso, 1999). Unfortunately, most of these areas have been exposed to grazing and fire mismanagement, resulting in shrub encroachment and the local disappearance of acceptable perennial forage grasses for cattle grazing (Fernández and Busso, 1999). As a result, rangelands of central Argentina have few warm-season, native perennial grasses that are acceptable forages to grazing livestock (i.e. Pappophorum vaginatum; Busso et al., 2004). Therefore, there is an imperative need to increase perennial grass species in this region (Anderson, 1980) to address the increasing cattle production and need for additional forage. Severe water stress, especially during the warm 
season, is another constraint the vegetation might eventually be exposed to (Giorgetti et al., 1997). The need to develop more appropriate forage resources for semi-arid grasslands and rangelands was emphasized by various researchers worldwide (Torres, 2010).

Various $\mathrm{C}_{3}$ perennial grass genotypes were worthy of consideration to complement use of the native/naturalized genotypes in our region. Those genotypes, coming from the western arid and semi-arid USA rangelands, included (i) Leymus cinereus cvs 'Magnar' and 'Trailhead' and (ii) Achnatherum hymenoides (Roemer \& J.A. Schultes) Barkworth cvs. 'Paloma', 'Nezpar' and 'Rimrock'. These genotypes grew during the warm, but not the cool, season in our region. An additional, warm-season, perennial grass tested in the region was Eragrostis curvula cv. 'Tanganyika'.

Results on productive performance and plant survival in native versus introduced species are scarce (Wilsey and Polley, 2006) and contradictory (Vilá and Weiner, 2004). There are examples where the introduced species have responded very flexibly and optimally to the colonized environment, either growing more vigorously or distributing more resources to reproduction (Maron et al., 2004). However, it needs to be considered that native species of any given environment are adapted to the local conditions of such environment. Therefore, greater plant establishment and persistence should often be expected for native than for introduced species. Insufficient water availability has, in the past, been the main cause of failures in the attempts of introducing plant species in arid rangelands (Bleak et al., 1966). These authors emphasized that appropriate management of native vegetation would be the best approach to achieve a good plant cover of forage that is acceptable to grazing livestock in those rangelands.

There are several examples, however, where introduced species have contributed to increased forage supply in cultivated and rangeland areas of Argentina and other countries: (i) Agropyron desertorum (Fischer ex Link) Shultes from Eurasia into the Western US rangelands; (ii) Eragrostis curvula (Schrader) Nees and Tetrachne dregei Nees, from South Africa into the cultivated area of the semi-arid Pampas region, and into the central rangelands of La Pampa Province, Argentina respectively; and (iii) Cenchrus ciliaris L. from Africa into the Catamarca Province, Argentina (Fernández et al., 1991; Briske and Richards, 1995; Ruiz and Terenti, 2012). Among the reasons for these successes are (i) a greater competitive ability than the native forage grasses and (ii) a high plasticity to various habitat conditions (i.e. extreme pHs, water stress, soil types; Fernández et al., 1991; Briske and Richards, 1995; Ruiz and Terenti, 2012). Therefore, we can expect that traits related with high competitive ability to various habitat conditions might be useful characteristics that could make plant introductions successful.

Several studies have been made on the morphophysiology, demography, plant growth and responses to grazing in P. vaginatum, L. cinereus, A. hymenoides and E. curvula (Fernández et al., 1991; Ogle et al., 2002; Torres et al., 2011). Although there are many studies, it is not clear yet which are the mechanisms responsible for grazing tolerance in these species. In addition, performance of the introduced genotypes might be different in Argentina than in other locations where previous work has been done. This is because climate and soil physico-chemical characteristics influence species introductions into degraded areas (De Graaf et al., 1998).

Tolerance to defoliation is given by the speed of photosynthetic surface reestablishment after such disturbance is produced (Briske and Richards, 1995). Rapid daughter-tiller production is a major factor contributing to defoliation tolerance (Briske and Richards, 1995). Timing of defoliation has direct effects on subsequent shoot growth rates, and plant dry-matter production and survival (Briske and Richards, 1995). Greater total leaf lengths have been produced after active meristems remain on the plant after defoliation (Becker et al., 1997). Therefore, we hypothesize that a greater daughter-tiller production in the native and naturalized than in the introduced grasses determine a greater dry-matter production in $P$. vaginatum and E. curvula than in the other introduced genotypes.

Objectives of this work were to compare productivity, survival and some morphological traits that might contribute to determine grazing tolerance of seven perennial grass genotypes (one native, one naturalized and five introduced) under two defoliation managements (undefoliated controls versus early and midseason defoliations) during each study growing cycle. These objectives would contribute to develop a better understanding of grass growth response to aid management.

\section{Materials and methods}

\section{Study site}

We conducted one study spanning 2 years (2007/2008 and 2008/2009), involving genotype and defoliation treatments, and multiple measurements. Studies were performed in the Chacra Experimental de Patagones, Buenos Aires, Argentina $\left(40^{\circ} 39^{\prime} S ; 6^{\circ} 53^{\prime}\right.$ W; 40 m.a.s.l.), within the Phytogeographical Province of the Monte (Cabrera, 1976).

Climate is temperate arid to semi-arid, with higher precipitations during the spring and autumn seasons 
(Giorgetti et al., 2000). Long-term (1981-2009) annual rainfall is $412.9 \pm 159 \mathrm{~mm}$ (mean $\pm 1 \mathrm{SD}$ ), with a mean annual temperature of $14.6^{\circ} \mathrm{C}$, absolute minimum temperature of $-7 \cdot 6^{\circ} \mathrm{C}$ (August), absolute maximum temperature of $43^{\circ} \mathrm{C}$ (January), mean annual relative humidity of $60 \%$, and mean annual wind speed of $13 \mathrm{~km} \mathrm{~h}^{-1}$. Mean rainfall values from September to May (the warm-season growing period) were 178 and $135 \mathrm{~mm}$ during 2007/2008 and 2008/ 2009 respectively. These values were lower than the long-term average (1981-2010; $336 \mathrm{~mm}$ ) during that growing period. Within the region, fertilization and irrigation are not an option: $55 \%$ of the years within the long-term mean (1981-2009: $412.9 \mathrm{~mm}$; range $=195.5-877.3 \mathrm{~mm}$ ) have shown an annual precipitation equal to or lower than $390 \mathrm{~mm}$. High variability in annual precipitation is typical of arid environments (Noy-meir, 1973). Climate conditions were registered by a meteorological station located at the study site and are depicted in Figure 1.

Soil is a typical Haplocalcid. Average $\mathrm{pH}$ is 7 , and depth is not a constraint in the soil profile. The plant community at the 'Monte' study region is characterized by an open, shrubby stratum which includes different quality, herbaceous species for cattle production (Giorgetti et al., 1997). Dominance of a particular grass or shrubby species in the study region is partially dependent on grazing history and fire frequency and intensity (Distel et al., 1996). A description of the study species is provided in Table 1 .

\section{Experimental design and defoliation managements}

Plants used in this study were obtained from seeds in the laboratory during spring 2005. Pre-germinated seeds were put on plastic pots $(10 \mathrm{~cm}$ diameter and $15 \mathrm{~cm}$ height) which remained under natural, rainfed conditions until transplanting time in 2006. Thereafter, this study was conducted on a natural grassland excluded from grazing; one exclosure $(30 \times 40 \mathrm{~m})$ to domestic livestock was established on this grassland. The natural vegetation within the exclosure was taken out from the soil by hand, trying to make the least amount of soil disturbance. The soil had not been cropped during at least the last 30 years. The experiment was initiated on November 2006, by establishing 98 single-genotype plots from 1-year-old transplant $[7$ genotypes (P. vaginatum; L. cinereus cvs. 'Magnar' and 'Trailhead'; A. hymenoides cvs. 'Paloma', 'Nezpar' and 'Rimrock'; E. curvula cv. Tanganyika) $\times 2$ defoliation managements (unclipped controls or plots clipped twice during the growing period) $\times 7$ replicate]. A completely randomized design was used during plot establishment. Each plot constituted an
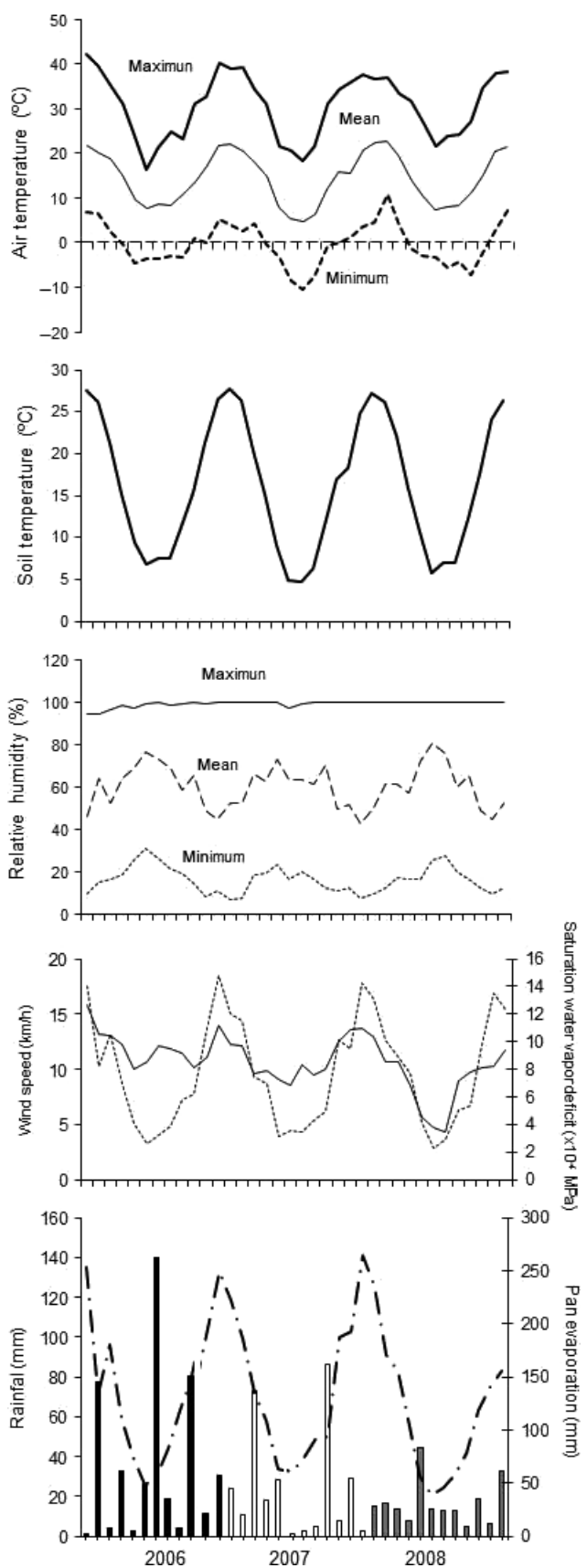

Figure I Absolute monthly maximum and minimum, and mean monthly air temperatures; mean monthly soil temperatures at 0-20 cm soil depth; absolute monthly maximum and minimum, and mean monthly relative humidities, mean monthly wind speed and saturation water vapour deficit, and mean monthly pan evaporation and monthly rainfall during 2006, 2007 and 2008 at a meteorological station located at the study site. Annual precipitations during 2006, 2007 and 2008 were $428.1 ; 287.5$ and $198.0 \mathrm{~mm}$ respectively. 
Table I Some major characteristics of the perennial grass genotypes used in this study

\begin{tabular}{|c|c|c|c|}
\hline Genotype & Origin & Description & Reference \\
\hline $\begin{array}{l}\text { Pappophorum } \\
\text { vaginatum }\end{array}$ & $\begin{array}{l}\text { North and Central, } \\
\text { up to northern Patagonia, } \\
\text { Argentina }\end{array}$ & $\begin{array}{l}\text { Warm-season, } \mathrm{C}_{4} \text { native bunchgrass } \\
\text { acceptable to grazing livestock } \\
\text { Mean biomass production } \\
(1984-1992)=560 \cdot 9 \pm 130 \cdot 8 \\
\mathrm{~kg} \mathrm{ha}^{-1} \text { year }{ }^{-1} \text { (mean } \pm 1 \mathrm{SE} \text { ); } \\
\text { reduced by overgrazing } \\
\text { Tolerant to frost while dormant } \\
\text { High seed production } \\
\text { Seeds cannot be seeded by } \\
\text { conventional drilling because of } \\
\text { disseminule morphology } \\
\text { (hairy anthecia + long awn) }\end{array}$ & $\begin{array}{c}\text { Cano (1988), Giorgetti et al. } \\
\text { (1997), Allen et al. (2011) }\end{array}$ \\
\hline $\begin{array}{l}\text { Leymus cinereus } \\
\text { cv. 'Magnar' }\end{array}$ & Saskatchewan, Canada & $\begin{array}{l}\text { Very drought tolerant, long-lived and } \\
\text { productive. It withstands flooding } \\
\text { Cool-season, } \mathrm{C}_{3} \text {, rhizomatous } \\
\text { genotype acceptable to grazing } \\
\text { livestock } \\
\text { Excellent for enhancing soil structure } \\
\text { Seeds can be seeded by conventional } \\
\text { drilling }\end{array}$ & $\begin{array}{l}\text { Majerus (1992), Johnson } \\
\text { et al. (2003), Allen et al. } \\
\text { (2011) }\end{array}$ \\
\hline $\begin{array}{l}\text { Leymus cinereus cv. } \\
\text { 'Trailhead' }\end{array}$ & Roundup, MT, USA & $\begin{array}{l}\text { Same as 'Magnar', but also it can } \\
\text { survive in areas with } 150 \mathrm{~mm} \\
\text { annual precipitation }\end{array}$ & $\begin{array}{l}\text { Majerus (1992), Johnson } \\
\text { et al. (2003), Chambers } \\
\text { and Miller (2004), Allen } \\
\text { et al. (2011) }\end{array}$ \\
\hline $\begin{array}{l}\text { Achanatherum } \\
\text { hymenoides cv. } \\
\text { 'Paloma', 'Nezpar' } \\
\text { and 'Rimrock' }\end{array}$ & $\begin{array}{l}\text { 'Paloma': Pueblo, CO, USA } \\
\text { 'Nezpar': Whitebird, ID, USA } \\
\text { 'Rimrock': Billings, MO, USA }\end{array}$ & $\begin{array}{l}\text { Excellent for rangeland improvement } \\
\text { and land reclamation } \\
\text { Densely tufted, very drought tolerant, } \\
\text { nutritious } C_{3} \text { bunchgrasses acceptable } \\
\text { to grazing livestock } \\
\text { Seeds can be seeded by conventional } \\
\text { drilling }\end{array}$ & $\begin{array}{l}\text { Jones (1990), Allen et al. } \\
\text { (2011) }\end{array}$ \\
\hline $\begin{array}{l}\text { Eragrostis curvula cv. } \\
\text { 'Tanganyika' }\end{array}$ & South Africa & $\begin{array}{l}\text { Warm-season, } \mathrm{C}_{4} \text { naturalized bunchgrass } \\
\text { acceptable to grazing livestock } \\
\text { Biomass production without fertilization } \\
\text { of a seeded forage crop was between } \\
4000 \text { and } 5000 \mathrm{~kg} \mathrm{ha}^{-1} \text { year }^{-1} \\
\text { depending on vegetation management } \\
\text { (without or with autumn resting from } \\
\text { livestock grazing respectively) } \\
\text { Tolerant to frost while dormant } \\
\text { Drought tolerant } \\
\text { Its establishment and subsequent } \\
\text { performance is limited to a series of } \\
\text { successive wet years } \\
\text { Seeds can be seeded by } \\
\text { conventional drilling }\end{array}$ & Fernández et al. (1991) \\
\hline
\end{tabular}

experimental unit. Defoliation managements were applied at random within each set of single-genotype plots. Plants on these plots were irrigated during spring 2006 and allowed to establish during a year previous to the study initiation in 2007/2008 and $2008 / 2009$. We used vigorous transplants, instead of obtaining plants directly from sowing at the field, to improve the likelihood of successful plant establish- 
ment. Within each plot, plant distance among plants in horizontal and vertical lines was $30 \mathrm{~cm}$ (from centre to centre on each plant crown; $3 \times 4=12$ plants). In this way, competitive relationships among plants were most likely similar. Similar approaches for transplant disposition within plots have been reported in other studies (Flemmer et al., 2002). During the study, plants were exposed to natural rainfall.

The first defoliation (i.e. clipping) was made using scissors during winter (the plant dormancy period) across all plants (i.e. across all plots) of the seven genotypes to remove aftermath in 2007. The purpose was that only aerial plant growth produced above $5 \mathrm{~cm}$ stubble during the subsequent warm growing season was used for sampling. This defoliation did not count as a treatment because plants were dormant at this time (i.e. aerial tissues were dead at this removal time, and thus it was not the commencement of the defoliation managements). Defoliating plants while they are in a dormant stage, with minimal physiological function, does not influence future plant performance (Schacht et al., 1998). Thereafter, plants in half of the plots were defoliated twice within each of the study growing cycles (i.e. the defoliation treatment was repeated for all plants on both dates in each growing cycle). During 2007/2008, defoliations were made on 5 and 11 November (mid-spring) 2007, and during 2008/2009, they were done on 19 November and 20 December 2008 (late spring). In the other half of the plots, the control plants were defoliated in winter 2007 and 2008 (i.e. during the dormancy developmental morphology stage) and in autumn 2008 and 2009 respectively, so their biomass was the forage accumulated during each growing season. Defoliation treatments were delayed in the second growing cycle because of a lower rainfall during September to December in 2008/2009 (see Figure 1: $62 \mathrm{~mm}$; i.e. a smaller plant growth) than in 2007/2008 (125.5 mm). This defoliation management mimics the short duration - high intensity, rotational-stocking system applied at the 'Monte' vegetation in the Chacra Experimental of Patagones (see Giorgetti et al., 2006 for details; mean $=29 \cdot 2$ animal unit ha ${ }^{-1}$ ). Within this system, some acceptable forage can be grazed twice by grazing livestock during their at least 30-day stay in the paddocks (Giorgetti, 1995). In Argentina, an animal unit is defined as the annual average dry forage requirement of a $400-\mathrm{kg}$ cow that goes through gestation and subsequent nursing of a calf, until the 160$\mathrm{kg}$, 6-month-old calf is weaned, including the forage consumed by the calf (Giorgetti et al., 2006). Defoliations were applied to the same plants in each year. In all cases, plants were defoliated leaving $5 \mathrm{~cm}$ stubble height. Defoliations were made during the vegetative stage and immediately after differentiation of the growth apex from vegetative to reproductive. It means that actively growing meristems (intercalary and leaf primordia in the growth apex) remained on the plants after the defoliation events.

We have to acknowledge that no plants that remained undefoliated throughout the entire study. Information on defoliation treatments and their purpose is summarized in Table 2.

\section{Measurements}

A summary of measurements made, measurements dates and why they were taken is provided in Table 3. A more detailed description follows:

\section{Height of the apical meristem}

Tillers of all seven genotypes were dissected every 2 weeks (Table 3) and observed under a binocular microscope to determine both the developmental stage and height of the apical meristem.

\section{Components of leaf-area production}

Tiller growth and demography were periodically determined. Ninety-eight randomly chosen plants were marked for this purpose (one per plot) in 2007/2008; we used 70 plants during 2008/2009 because $A$. hymenoides cvs. 'Nezpar' and 'Rimrock' were unable to persist after the drought years and defoliation managements. On each one of these plants, one currentseason tiller was permanently marked with wire cables. Plant circumference of green basal areas (used to calculate total green basal area), number of total tillers and number of daughter tillers produced by each marked tiller were determined on each plant. Total tiller number per plant was divided by total green basal area to obtain tiller number per square centimetre. In addition, total leaf length [blades + sheaths (green + dry)] was measured on each marked tiller. These measurements followed those of Busso et al. (2003). Total leaf length data were used to calculate growth rates following Larcher (2003). The timing for the measurement of each variable is indicated in Table 3.

\section{Aboveground biomass production}

Aboveground biomass was harvested using scissors at the time of defoliation (springs 2007 and 2008) on defoliated plants, and at the end of the growing seasons (autumns 2008 and 2009) in all study plants. This allowed us to obtain the total aboveground biomass productions of defoliated plants and undefoliated controls during 2007/2008 and 2008/2009. All 
Table 2 Summary of applied treatments, treatment dates and purposes. Plant used during the second growing cycle (2008/ 2009) received the same treatments than those on the first growing cycle (2007/2008)

\begin{tabular}{|c|c|c|}
\hline Treatment & $\begin{array}{l}\text { Date of treatment } \\
\text { (season; plant developmental } \\
\text { morphology stage) }\end{array}$ & Purpose of treatment \\
\hline $\begin{array}{l}\text { Removal of aftermath at } 5 \mathrm{~cm} \text { stubble } \\
\text { height on all study plant (this was not } \\
\text { the commencement of the defoliation } \\
\text { treatments) }\end{array}$ & $\begin{array}{l}1 \text { August } 2007 \\
\text { (mid-winter; dormancy) }\end{array}$ & $\begin{array}{l}\text { To determine aerial plant growth produced } \\
\text { above } 5 \mathrm{~cm} \text { stubble during the following } \\
\text { warm growing season, and various traits } \\
\text { related to plant growth (see Table 3), as } \\
\text { affected by two defoliation managements } \\
\text { (clipping; unclipped controls) }\end{array}$ \\
\hline \multicolumn{3}{|l|}{ Defoliated (clipped) plant } \\
\hline $\begin{array}{l}\text { First year of treatment during the } \\
2007 / 2008 \text { growing cycle }\end{array}$ & $\begin{array}{l}5+11 \text { November } 2007 \text { (mid-spring; } \\
\text { actively growing tissues) + } 30 \text { May } \\
2008 \text { (late autumn; dormancy) }\end{array}$ & $\begin{array}{l}\text { To evaluate the cumulative effects of the first } \\
\text { year of two defoliations on the same plant } \\
\text { within the growing cycle on total plant } \\
\text { production and various traits related to it } \\
\text { (see Table } 3 \text { for measurements) }\end{array}$ \\
\hline $\begin{array}{l}\text { Second year of treatment during the } \\
2008 / 2009 \text { growing cycle }\end{array}$ & $\begin{array}{l}19 \text { November }+20 \text { December } 2008 \\
\text { (late spring; actively growing } \\
\text { tissues) }+3 \text { June } 2009 \text { (late autumn; } \\
\text { dormancy) }\end{array}$ & $\begin{array}{l}\text { To evaluate the cumulative effects of a second } \\
\text { year of two defoliations on the same plant } \\
\text { within the growing cycle on total plant } \\
\text { production and various traits related to it } \\
\text { (see Table } 3 \text { for measurements) }\end{array}$ \\
\hline \multicolumn{3}{|l|}{ Undefoliated plant } \\
\hline First year of treatment & 30 May 2008 (late autumn; dormancy) & $\begin{array}{l}\text { To evaluate total plant production, and } \\
\text { various traits related to it (see Table } 3 \text { for } \\
\text { measurements), during the first study } \\
\text { growing cycle }\end{array}$ \\
\hline Second year of treatment & 3 June 2009 (late autumn; dormancy) & $\begin{array}{l}\text { To evaluate total plant production, and various } \\
\text { traits related to it (see Table } 3 \text { for } \\
\text { measurements), during the second study } \\
\text { growing cycle }\end{array}$ \\
\hline
\end{tabular}

plant materials were dried at $70^{\circ} \mathrm{C}$ for $72 \mathrm{~h}$ and weighed.

\section{Plant survival}

At the end of autumn 2008 and 2009, number of surviving plants (SP; plants which regrow and continue growing) was counted in each of the 98 experimental plots. This allowed the calculation of percentage plant survival (PS) at a plot scale as:

$$
P S=S P / I N \times 100,
$$

where IN = initial plant number/plot $(=12)$.

\section{Statistical analyses}

Our treatments were combinations of genotype $\times$ defoliation management. Therefore, we used a factorial treatment design $(7$ genotypes $\times 2$ clipping managements) with seven replications/treatment. Data were analysed using the statistical software INFOSTAT (Di Rienzo et al., 2009). Variables that were periodically evaluated were analysed using repeatedmeasures two-way anova. A mixed model ANova was used where genotype, defoliation management and genotype $\times$ defoliation management were considered fixed effects, and sampling date, replication, and three-way interactions with sampling dates were considered random effects. The multivariate approximation was used using the statistics of Wilks (1932). Whenever an average for all sampling dates (within each of the study years) is provided for any given variable within each defoliation management and genotype, it indicates that the multivariate analysis conducted using the Wilks' statistics was not significant $(P>0.05)$. Otherwise, data are reported for each sampling date because of the interaction $(P<0.05)$ between the factors (defoliation managements, genotypes) and the sampling dates. Numbers of daughter tillers/parent tiller were transformed to $\sqrt{ }(x+0 \cdot 5)$, and total dry-matter production data were transformed to 
Table 3 A summary of measurements (unit) taken, and date and purpose of measurements. Results were expressed on a per unit surface area basis (i.e. per square centimetre) because of inherent differences in tiller density (tiller number per square centimetre) and plant basal area among genotypes

\begin{tabular}{|c|c|c|}
\hline Measurements & Date of measurements & Purpose of measurements \\
\hline Apical meristem height $(\mathrm{cm})$ & $\begin{array}{l}\text { 2007/2008: } 10 \text { and } 24 \text { September; } \\
8 \text { and } 22 \text { October; } 9 \text { November } \\
\text { 2008/2009: } 9 \text { and } 23 \text { September; } \\
7 \text { and } 21 \text { October; } 1 \text { and } 18 \\
\text { November; } 2 \text { and } 16 \text { December }\end{array}$ & $\begin{array}{l}\text { To determine height of the tiller apical } \\
\text { meristem as to leave it on the plant after } \\
\text { the defoliation managements }\end{array}$ \\
\hline Plant circumference $(\mathrm{cm})$ & $\begin{array}{l}\text { 2007/2008: } 30 \text { September; } 25 \text { October; } \\
24 \text { November; } 27 \text { December; } \\
23 \text { January; } 29 \text { February } \\
\text { 2008/2009: } 17 \text { October; } 18 \text { November; } \\
17 \text { December; } 22 \text { January; } 26 \text { February }\end{array}$ & $\begin{array}{l}\text { To calculate plant basal area, and thereafter } \\
\text { express results on a per unit surface area } \\
\text { basis (i.e. } \mathrm{cm}^{2} \text { ), on all study genotypes }\end{array}$ \\
\hline Total (live + dry) plant tiller number & $\begin{array}{l}\text { Same as for plant circumference } \\
\text { in both years }\end{array}$ & $\begin{array}{l}\text { To determine the cumulative effects of } \\
\text { defoliation on total plant tiller number, } \\
\text { as a measure of plant size on the study } \\
\text { genotypes. }\end{array}$ \\
\hline Number of daughter tillers/parent tiller & $\begin{array}{l}\text { Same as for plant circumference } \\
\text { in both years }\end{array}$ & $\begin{array}{l}\text { To determine whether, immediately after } \\
\text { defoliation, any of the study genotypes } \\
\text { showed higher production of daughter } \\
\text { tillers than the undefoliated controls as a } \\
\text { measure of defoliation tolerance }\end{array}$ \\
\hline $\begin{array}{l}\text { Total tiller leaf length [blades }+ \text { sheaths } \\
\text { (green }+ \text { dry); } \mathrm{cm}]\end{array}$ & $\begin{array}{l}\text { Same as for plant circumference } \\
\text { in both years }\end{array}$ & $\begin{array}{l}\text { To determine the effects of the defoliation } \\
\text { managements on leaf growth of the study } \\
\text { genotypes at a tiller scale }\end{array}$ \\
\hline Total dry weight production (g) & $\begin{array}{l}\text { 2007/2008: } 25 \text { April } 2008 \\
\text { 2008/2009: } 5 \text { May } 2009\end{array}$ & $\begin{array}{l}\text { To evaluate the effects of the defoliation } \\
\text { managements on total dry weight } \\
\text { production of the study genotypes at the } \\
\text { end of the growing cycles, after studying } \\
\text { some major factors (see measurements } \\
\text { above) that determine it }\end{array}$ \\
\hline Plant survival & $\begin{array}{l}\text { 2007/2008: } 25 \text { April } 2008 \\
\text { 2008/2009: } 5 \text { May } 2009\end{array}$ & $\begin{array}{l}\text { To evaluate the effects of the defoliation } \\
\text { managements on plant survival of the } \\
\text { study genotypes at the end of each of the } \\
\text { study growing cycles }\end{array}$ \\
\hline
\end{tabular}

$\ln (x+1)$ to comply with the normality and homoscedasticity assumptions of variance (Sokal and Rohlf, 1984). Untransformed values are shown in illustrations. In all two-way Anova where the interaction genotype $\mathrm{x}$ defoliation management was significant, both factors were analysed separately. Plant survival was analysed using two-way ANOva. Mean separation was conducted using protected LSD, with $P \leq 0.05$. Some results were expressed on a per square centimetre basis for comparative purposes, because of plant size differences among the study genotypes. Combined analysis across the study years was not conducted because they showed similar $(P>0.5)$ monthly precipitation and temperature values during the study warm growing seasons.

\section{Results}

\section{Height of the apical meristem}

Mean height of the apical meristem at the time of the defoliation managements in 2008 and 2009 was less than or equal to $9.43 \pm 0.90 \mathrm{~mm}$ (mean $\pm 1 \mathrm{SE}$, $n=14$ ) in all seven genotypes.

\section{Green-plant basal area}

Green-plant basal areas were at least $40 \%$ greater in the native (mean $\pm \mathrm{SD}: \quad 77 \cdot 1 \pm 16 \cdot 3 \mathrm{~cm}^{2}, \quad n=22$ ) than in the introduced genotypes $\left(34.0 \pm 13.0 \mathrm{~cm}^{2}\right.$, $n=90$ ) on average for $2007 / 2008$ and $2008 / 2009$. The 
only exception was E. curvula cv. Tanganyika that showed at least a $47 \%$ greater green basal area than the other six genotypes on average for both years (data not shown). Because of differences in greenplant basal areas among genotypes, most of the traits will be presented on a per square centimetre basis for comparative purposes.

\section{Tiller growth and demography}

\section{Tiller number per plant}

Before defoliation in 2007/2008, tiller numbers of defoliated and undefoliated plants in the native species were similar $(P>0.05)$ to those in $L$. cinereus cv. 'Magnar', and A. hymenoides cvs. 'Paloma' and 'Rimrock' (Figure 2). A similar $(P>0.05)$ result was obtained immediately after defoliation on 24 November (data not shown). During early summer (27 December), A. hymenoides 'Paloma' showed a 56\% greater $(P<0.05)$ tiller number than the native species and the remaining introduced genotypes. At the end of the growing season (29 February), tiller numbers of defoliated and undefoliated plants were similar $(P>0.05)$ in the native species, and in A. hymenoides cvs. 'Paloma' and 'Rimrock' (Figure 2). At this time, tiller numbers on defoliated and undefoliated plants of the native species were similar $(P>0.05)$ to those on undefoliated plants of $L$. cinereus cv. 'Magnar'; defoliation increased $(P<0.05)$ tiller numbers in A. hymenoides cv. 'Rimrock' and decreased $(P<0.05)$ them in L. cinereus cv. 'Trailhead' (Figure 2 ). Other than these cases, defoliated and undefoliated plants showed a similar $(P>0.05)$ tiller number in the native and introduced genotypes. Defoliated and undefoliated plants of E. curvula cv. 'Tanganyika' showed the greatest $(P<0.05)$ tiller numbers among all genotypes, but on undefoliated A. hymenoides cv. 'Paloma', during the full growing season. By early (23 January) and late (29 February) summer, tiller numbers were greater $(<0.05)$ on defoliated than on undefoliated plants of E. curvula cv. 'Tanganyika' (Figure 2).

At the beginning of the 2008/2009 growing season (17 October), tiller numbers were similar $(P>0.05)$ in the native species and in L. cinereus cvs. 'Magnar' and 'Trailhead' (Figure 2). However, after the first and second defoliations towards the end of the growing season, tiller numbers were greater $(P<0.05)$ in the native genotype than in L. cinereus cvs. 'Magnar' and 'Trailhead', and A. hymenoides cv. 'Paloma' (Figure 2). From mid-spring (18 November) onwards, tiller numbers were similar $(P>0.05$; overall mean undefoliated plants: $51.4 \pm 3.0$, defoliated plants: $38.1 \pm 1.6$ ) in the native and naturalized genotypes (Figure 2). Also, from mid-spring to the end of the growing season,

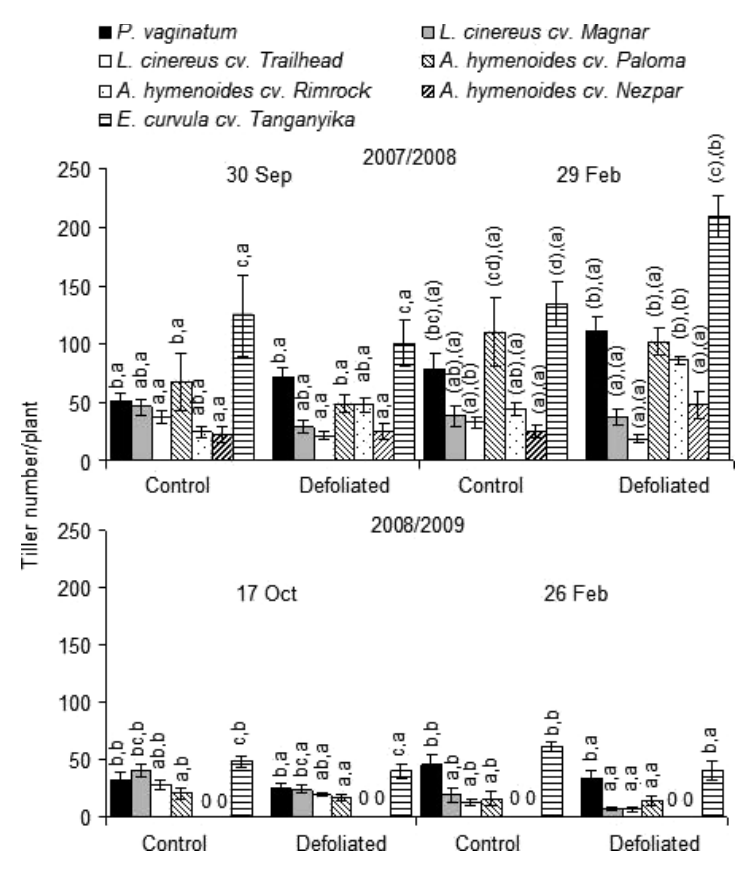

Figure 2 Tiller numbers on plants of seven (2007/2008) or five genotypes (2008/2009) exposed to two defoliation managements (Control, Defoliated) during the growing seasons of $2007 / 2008$ and 2008/2009. All plants were obtained from seeds. Each histogram is the mean \pm 1 SE of $n=7$. Different letters above histograms indicate significant differences $(P<0.05)$ among genotypes (first letter) or between defoliation managements (second letter). Letters in parenthesis indicate that there was an interaction $(P<0.05)$ between genotype and defoliation management. In these cases, differences $(P<0.05)$ among genotypes within each defoliation management (first letter) and between defoliation management within each genotype (second letter) are indicated in parenthesis. Presence of zero values indicates dead plants.

defoliated plants showed at least a $12.4 \%$ lower $(P<0.05)$ tiller number than the undefoliated controls in the native and naturalized genotypes, and in L. cinereus cvs. 'Magnar' and 'Trailhead', and A. hymenoides cv. 'Paloma' (Figure 2).

Tiller number per plant across all genotypes increased by more than $19 \%$ on undefoliated and $88 \%$ on defoliated plants from early spring to late summer in 2007/2008 (Figure 2). However, during early spring and late summer of the next year, tiller number per plant across all genotypes had decreased at least 54\% on defoliated and undefoliated plants (Figure 2).

\section{Tiller number per square centimetre}

Defoliation management and genotype interacted with time in $2007 / 2008$ and $2008 / 2009$. This is because 
data were analysed within each date. During most of the sampling dates during the first and second years, defoliated and undefoliated plants showed a similar $(P>0.05)$ tiller number per square centimetre $(30$ September: $1.46 \pm 0 \cdot 18,25$ October: $1.45 \pm 0.15$ and 24 November 2007: $1.38 \pm 0 \cdot 15 ; 29$ February: $1 \cdot 85 \pm 0 \cdot 19,17$ October: $0.50 \pm 0 \cdot 08,18$ November: $0 \cdot 52 \pm 0 \cdot 10$, and 17 December 2008: $0.53 \pm 0 \cdot 11 ; 22$ January: $0.47 \pm 0.11$, and 26 February 2009: $0 \cdot 35 \pm 0 \cdot 10)$. The only exceptions were on 27 December 2007 and 23 January 2008, when tiller number per square centimetre was lower $(P<0.05)$ on undefoliated (2007: $1.43 \pm 0.24 ; 2008: 1.71 \pm 0.30)$ than on defoliated (2007: $1.88 \pm 0.21 ; 2008: 2 \cdot 35 \pm 0 \cdot 30$ ) plants.

During the first and second years, tiller number per square centimetre was similar $(P>0.05)$ between the native and naturalized genotypes (Figure 3). In both years, this variable was similar $(P>0.05)$ or greater $(P<0.05)$, but not lower, in the introduced than in the native or naturalized genotype (Figure 3). Plants of A. hymenoides cvs. 'Rimrock' and 'Nezpar', however, were dead by the initiation of the second year.

The reduction in tiller number per square centimetre across all genotypes between the first and second years was $>78 \%$ (Figure 3 ).

\section{Daughter-tiller production per unit surface area}

Defoliated and undefoliated plants of A. hymenoides cvs. 'Paloma' and 'Rimrock' showed a greater $(P<0.05)$ daughter-tiller production than the native and the remaining genotypes in 2007/2008 (Figure 4). In this year, production of daughter tillers by the native species was similar $(P>0.05)$ to that of $L$. cinereus cv. 'Trailhead', A. hymenoides cv. 'Nezpar' and E. curvula cv. 'Tanganyika' and greater $(P<0.05)$ than that of L. cinereus cv. 'Magnar' (Figure 4). During the following growing season (2008/2009), however, the greatest $(P<0.05)$ daughter-tiller production was determined in the native genotype, and production of daughter tillers was similar $(P>0.05)$ in the remaining six genotypes (Figure 4). In 2007/2008 and 2008/ 2009 , daughter-tiller production was similar $(P>0.05)$ on defoliated vs undefoliated plants in all genotypes (Figure 4).

Between the first and second years, the reduction in the production of daughter tillers across all, but the native, genotypes was $>90 \%$ on defoliated or undefoliated plants (Figure 4). The only exception was the defoliated and undefoliated plants of P. vaginatum, which maintained an overall daughter-tiller production of $0.0100 \pm 0.0004$ tillers per square centimetre between both years (Figure 4).

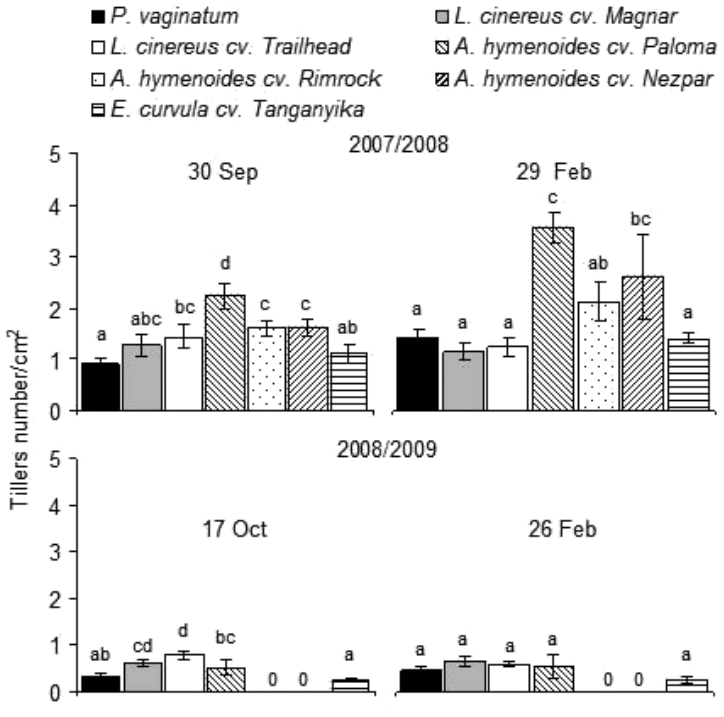

Figure 3 Tiller numbers per square centimetre of seven (2007/2008) or five genotypes (2008/2009) exposed to two defoliation managements (Control, Defoliated) during the growing seasons of 2007/2008 and 2008/2009. All plants were obtained from seeds. Data for Control and Defoliated plants were pooled after there were no significant differences $(P>0.05)$ among them. Each histogram is the mean \pm I SE of $n=14$. Within each date, different letters above histograms indicate significant differences $(P<0.05)$ among genotypes. Presence of zero values indicates dead plants.

\section{Total leaf length}

Before defoliation in 2007/2008, total leaf length per unit surface area was similar $(P>0.05)$ (i) among genotypes and (ii) between defoliated and control plants (Figure 5). The only exception was $A$. hymenoides cv. 'Nezpar' that showed greater $(P<0.05)$ total leaf length than that in the other genotypes (Figure 5). After the two defoliations events in 2007, defoliated and undefoliated plants of (i) Leymus cinereus cv. 'Trailhead', and A. hymenoides cvs. 'Rimrock' and 'Nezpar' on 24 November 2007; (ii) A. hymenoides cv. 'Nezpar' on 27 December 2007; (3) L. cinereus cvs. 'Magnar' and 'Trailhead', and A. hymenoides cvs. 'Paloma' and 'Nezpar' on 23 January 2008, and (iv) L. cinereus cvs. 'Magnar' and 'Trailhead' and A. hymenoides cv. 'Nezpar' on 29 February 2008 showed at least 150\% greater $(P<0.05)$ total leaf lengths than those on the native species (Figure 5).

After defoliation, total leaf length was at least $15 \%$ lower $(P<0.05)$ on defoliated than on undefoliated plants in all genotypes from 24 November 2007 to 29 February 2008 (Figure 5). The only exception was on L. cinereus cv. 'Magnar' where total leaf length was 


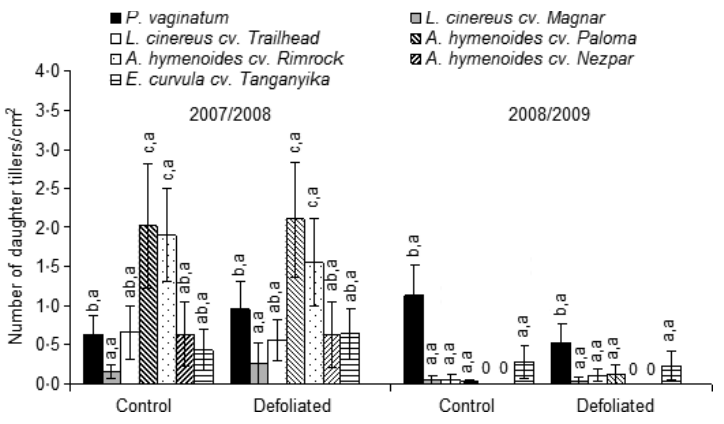

Figure 4 Number of daughter tillers per square centimetre on plants of seven (2007/2008) or five genotypes (2008/ 2009) exposed to two defoliation managements (Control, Defoliated) during the growing seasons of 2007/2008 and $2008 / 2009$. Each histogram is the mean \pm I SE of $n=42$ (2007/2008) or $n=35$ (2008/2009). Within each growing cycle, different letters above histograms indicate significant differences $(P<0.05)$ among genotypes (first letter) or between defoliation managements (second letter). Presence of zero values indicates dead plants.

similar $(P>0.05)$ on defoliated than on undefoliated plants on 29 February 2008 (Figure 5).

In the next growing cycle (2008/2009), defoliated and undefoliated plants of (i) L. cinereus cvs. 'Magnar' and 'Trailhead' and A. hymenoides cv. 'Paloma' on 17 October and (ii) L. cinereus cvs. 'Magnar' and 'Trailhead' on 18 November showed greater $(P<0.05)$ total leaf length than the native species (Figure 5). On 17 October and 18 November 2008/2009, defoliated and undefoliated plants showed similar $(P>0.05)$ total leaf lengths in all genotypes (Figure 5). From 17 December 2008 to 26 February 2009, total leaf length was on average more than $70 \%$ greater $(P<0.05)$ in L. cinereus $\mathrm{cv}$. 'Trailhead' than in the native genotype, L. cinereus cv. 'Magnar', A. hymenoides cv. 'Paloma' and E. curvula cv. 'Tanganyika' (data not shown). Once again, defoliated and undefoliated plants showed a similar $(P>0.05)$ total leaf length in $P$. vaginatum, L. cinereus cvs. 'Magnar' and 'Trailhead', A. hymenoides cv. 'Paloma' and E. curvula cv. 'Tanganyika' (data not shown).

In early spring, the total leaf-length reduction across all genotypes from 2007 to 2008 was $80.9 \%$ on control plants and $78.3 \%$ on defoliated plants (Figure 5). By late summer, the reduction in total leaf length across all genotypes between the first and second years was more than $66 \%$ on defoliated and undefoliated plants (data not shown).

\section{Total dry-weight production}

No significant differences $(P>0.05)$ in production of total dry weight were found among genotypes during

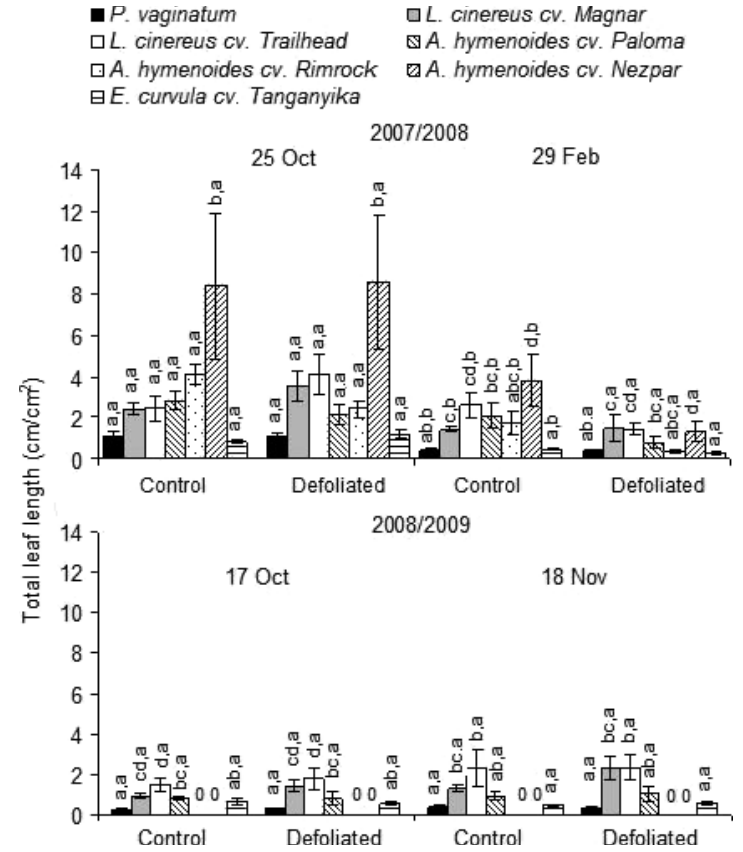

Figure $\mathbf{5}$ Total leaf length [length of total blades + sheaths (green $+\mathrm{dry}) / \mathrm{cm}^{2} ; \mathrm{cm} / \mathrm{cm}^{2}$ ] on plants of seven (2007/2008) or five genotypes (2008/2009) exposed to two defoliation managements (Control, Defoliated) during the growing seasons of 2007/2008 and 2008/2009. Each histogram is the mean \pm I SE of $n=7$. Within each growing cycle, different letters above histograms indicate significant differences $(P<0.05)$ among genotypes (first letter) or between defoliation managements (second letter). Presence of zero values indicates dead plants.

2007/2008 (Figure 6). At the same time, however, total dry-weight production was greater $(P<0.05)$ on defoliated than on undefoliated plants of all genotypes (Figure 6). During 2008/2009, L. cinereus cv. 'Magnar' showed a greater $(P<0.05)$ total dry-weight production than the native genotype, while production of total dry weight was similar $(P>0.05)$ in $P$. vaginatum, in L. cinereus cv. 'Trailhead', A. hymenoides cv. 'Paloma' and E. curvula cv. 'Tanganyika' (Figure 6). Total dryweight production was similar $(P>0.05)$ on defoliated versus undefoliated plants in all study genotypes in 2008/2009 (Figure 6).

There was a substantial reduction in total dryweight production across the genotypes on defoliated $(76 \cdot 1 \%)$ and undefoliated $(59.7 \%)$ plants between the first and second years (Figure 6).

\section{Plant Survival}

Greatest $(P<0.05)$ percentage survival at the end of the 2007/2008 growing season was found on defoliated 


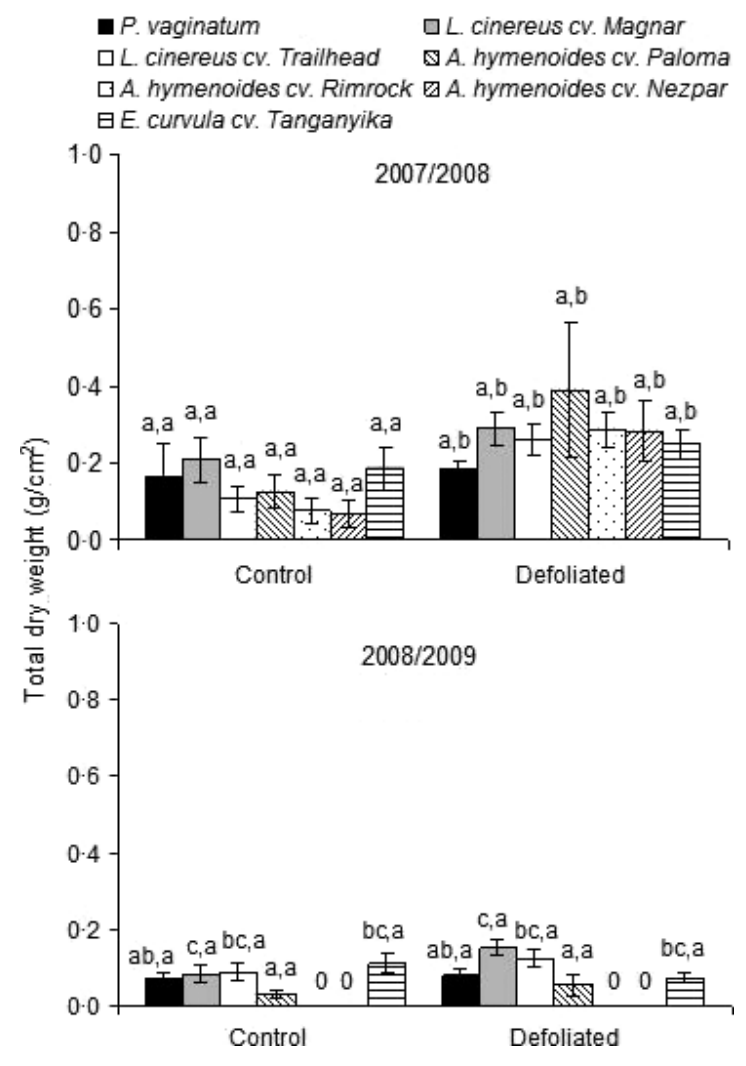

Figure 6 Total dry-weight production per square centimetre in $2007 / 2008$ or $2008 / 2009$ on plants of seven (2007/2008) or five genotypes (2008/2009) exposed to two defoliation managements (Control, Defoliated). Each histogram is the mean \pm I SE of $n=7$. Within each growing cycle, different letters above histograms indicate significant differences $(P<0.05)$ among genotypes (first letter) or between defoliation managements (second letter). Presence of zero values indicates dead plants.

and undefoliated plants of the native $($ mean $=83.3 \%$ ) and naturalized $($ mean $=74 \cdot 4 \%)$ genotypes (Figure 7 ). These values approximately double those found in the introduced genotypes (overall mean $=36.9 \%$ ), but A. hymenoides CV. 'Nezpar' presented the lowest $(P<0.05)$ plant survival (Figure 7$)$. During the second growing season (2008/2009), defoliated and undefoliated plants of the native species showed the greatest $(P<0.05)$ plant survival (mean $=71.4 \%$, Figure 7$)$. Percentage survival was on average $35 \%$ lower $(P<0.05)$ in the naturalized genotypes that presented greater $(P<0.05)$ values than on those introduced (Figure 7). Defoliated and undefoliated plants of $A$. hymenoides cvs. 'Nezpar' and 'Rimrock' were dead at the end of the 2008/2009 growing cycle (Figure 7). Plant survival was greater on undefoliated than defoliated

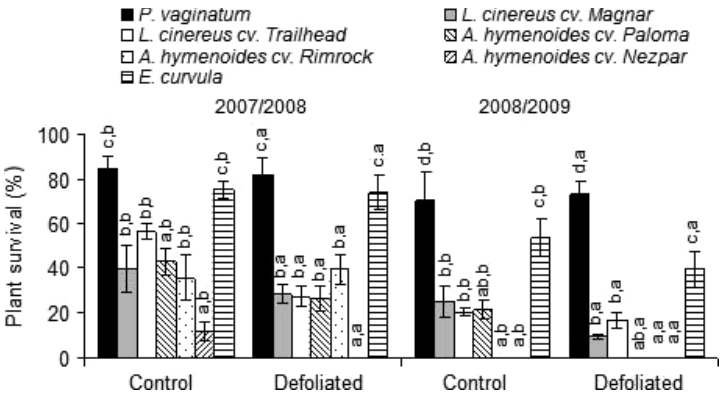

Figure 7 Percentage survival of seven genotypes exposed to two defoliation managements (Control, Defoliated) at the end of the growing seasons of 2007/2008 or 2008/2009. Each histogram is the mean \pm 1 SE of $n=7$. Absence of histograms indicates zero values (i.e. dead plants). Within each growing cycle, different letters above histograms indicate significant differences $(P<0.05)$ among genotypes (first letter) or between defoliation managements (second letter).

plants across all genotypes during both growing seasons (Figure 7).

\section{Discussion}

At least during the first 3 years of growth and development in these species, height of the growth apex was below $1 \mathrm{~cm}$ from the soil surface during spring in the north-western region of arid Patagonia, Argentina. This finding is important because livestock could graze L. cinereus genotypes during spring without removing most active intercalary and apical meristems, at least during the first 2 years after plant establishment. This means that growth will continue to be rapid after spring grazing, because growth rate is fastest from intercalary meristems, intermediate from the leaf primordial in the growth apex and lowest from the activation and subsequent outgrowth of the axillary buds (Briske and Richards, 1995). As active meristems remained on the plant after the defoliation events, they might be able to recuperate their tissues lost to defoliation. However, the fact that active meristems measured in this study were at $1 \mathrm{~cm}$ did not guarantee persistence of $L$. cinereus in our study. This was the result of the fact that Leymus genotypes defoliated at $5 \mathrm{~cm}$, in a spaced plant situation, lost $60 \%$ of the plants in the first season and more than $80 \%$ in the second. Other studies in the western rangelands of the USA have reported that this genotype needs to be clipped to no less than $30 \mathrm{~cm}$ height for reducing grazing damage (USDA, NRCS, 2000).

Plants of Eragrostis curvula cv. 'Tanganyika' showed the greatest basal area during the first and second years and the greatest tiller number per plant during 
the first growing season among all genotypes. Fernández et al. (1991) reported that vegetative tillers in E. curvula cv. 'Tanganyika' multiply rapidly during the growing season, that is, hundreds of them can be originated on a plant basis during the plant establishment year under favourable biotic and abiotic conditions. During the first year, defoliation increased tillering in E. curvula. Tillers at the periphery are often exposed to a greater radiation intensity than those at the plant centre, where shading might be high (Briske and Richards, 1995). Defoliation might have reduced shading and increased the quantity and quality of light reaching the crown at the plant centre. The positive effects of defoliation on tillering of E. curvula were only shown during the first year. During the second year, tiller numbers per plant in December on plants of all genotypes and those of E. curvula were similar to those in the native species from before the first defoliation to the end of the growing season.

The cumulative effects of two successive years of severe defoliations reduced tiller number on plants of all genotypes. These adverse effects of defoliation on tillering of perennial grasses have been reported by various authors (Briske and Richards, 1995). Defoliation has caused (i) inhibitory effects on activation and viability of axillary buds (Busso et al., 1989); (ii) a reduction in carbon reserve availability that allows initial re-growth when a photosynthetic surface area is not available after a disturbance (Busso et al., 1990); and (iii) a lower survival of growing tillers (Busso et al., 1989).

Plants of the native species showed a greater basal area and had a similar or lower tiller number than those of the introduced genotypes, especially with respect to L. cinereus, after the first-year defoliations. At this time (i.e. end of the first growing season), tiller number on defoliated plants was similar to or greater than, but not lower than, that on undefoliated controls in all genotypes (but L. cinereus cv. 'Trailhead'), which is an indication of defoliation tolerance. Pappophorum vaginatum was affected by defoliation during the second study year, which produced a reduction in the basal area of their plants. The only genotype that showed an equal or greater tiller number per plant than $P$. vaginatum in the first growing season was A. hymenoides cv. 'Paloma'. This introduced species was unable to have a greater basal area, but its tillers were thinner (Torres, 2010) than those in the native genotype.

At the beginning of the growing season, regrowth from axillary meristems was about 3 weeks earlier in L. cinereus CV. 'Magnar' than in P. vaginatum. This response in cV. 'Magnar' would contribute to an earlier occupancy of the more favourable soil parcels, which in turn should improve competitive effective- ness. Favourable soil microsites may be important areas of root competition (e.g. Jackson and Caldwell, 1989). This could help explain the earlier shoot regrowth in early spring in $L$. cinereus than in $P$. vaginatum. The fact that the $C_{3}$ genotype started growth earlier than the $\mathrm{C}_{4}$ one agrees with the report of Niu et al. (2008). These authors stated that the $C_{3}$ species begin growth in early spring, soon after the soil temperature is above freezing, while $\mathrm{C}_{4}$ species grow during warmer periods.

In the two study growing seasons, total leaf length was most often greater in the introduced Achanatherum or Leymus species than in the native genotype. Moreover, total leaf length in 2007/2008 was greater on defoliated than on undefoliated plants of L. cinereus cV. 'Magnar', thus showing tolerance to defoliation. At the end of the 2008/2009 growing season, total leaf length produced between the second defoliation in 2008, and the end of the experiment, was similar on defoliated than on undefoliated plants in all study genotypes. This indicates that leaves grew faster on defoliated than on undefoliated plants after defoliation to reach equal total leaf lengths at the end of the growing season.

Except for L. cinereus cv. 'Magnar', where daughter-tiller production was greater in the native than in the introduced genotype, daughter-tiller production was similar or greater in the introduced genotypes than in the native species in the first growing season (2007/2008: 222.5 mm from September 2007 to May 2008; $123 \mathrm{~mm}$ from September to November 2007). The dry 2008/2009 growing season (September 2008 to May 2009: $131.5 \mathrm{~mm} ; 29.5 \mathrm{~mm}$ from September to November 2008) might have contributed to determine a lower daughter-tiller production in the introduced and naturalized than in the native genotype. In both years, daughter-tiller production was similar on defoliated than on undefoliated plants in all genotypes. This means that defoliation did not hinder daughter-tiller production, which we know contributes to defoliation tolerance (Briske and Richards, 1995), even under dry conditions.

The serious reduction in tiller numbers, especially daughter-tiller numbers, on defoliated and undefoliated plants across all genotypes from the first to the second year might be in part the result of the dry growing season in 2008/2009. Tiller number is an indication of bud outgrowth (Busso et al., 1989). These authors emphasized that defoliated tillers on droughttreated plants of the bunchgrass Pseudoroegneria spicata (Syn: Agropyron spicatum) showed a significantly lower number of physiologically active buds than tillers on undefoliated controls in that treatment. Flemmer et al. (2002) also determined in various perennial grasses that the proportion of stem bases producing tillers per 
plant was much lower under water stress than under higher levels of soil-moisture availability. Additionally, crown and total (crown + roots) pools of total nonstructural carbohydrates were positively associated with early spring tiller regrowth on two perennial bunchgrass species (Busso et al., 1990). Therefore, we suggest that the great reduction in tiller numbers from one year to the next in our study could be a sign of a depleted plant in both axillary bud bank and energy reserves. These two factors might have contributed to the high plant mortality at the end of the study in the introduced genotypes. Additionally, Hodgkinson (2010) reported that the density of live tillers generally declined on plants of the perennial grasses Ausrodanthonia auriculata, Bothriochloa macra, E. curvula, Phalaris aquatica and Themeda triandra as they remained under drought conditions. Furthermore, he showed that the death of plants in the drought treatment began for all species very soon after the foliage of plants had died. Hodgkinson (2010) determined a critical threshold for days in drought beyond which all plants of any of his study species would die, which was species dependent: about 100 days for A. auriculata, P. aquatica and T. triandra, 200 days for B. macra and 300 days for E. curvula.

After the second defoliation in $2007 / 2008$, by midspring, growth rates (on a total leaf-length basis) were between $0.009 \pm 0.001$ and $0.205 \pm 0.081 \mathrm{~cm} \mathrm{~cm}^{-2} \mathrm{~d}^{-1}$ on defoliated and $0 \mathrm{~cm} \mathrm{~cm}^{-2} \mathrm{~d}^{-1}$ on undefoliated plants of all genotypes. Rapid leaf replacement after defoliation is a critical component of defoliation tolerance in various perennial grass species (Briske and Richards, 1995). The number of active meristems and the amount of residual photosynthetic surface area have been reported to be more important than carbon reserves in limiting regrowth rates on defoliated plants (Richards and Caldwell, 1985). Also, changes in environmental conditions, especially at the level of apical meristems, have fostered leaf growth on defoliated plants (Briske and Richards, 1995). Rapid leaf replacement after defoliation in other grasses has been attributed to compensatory photosynthesis on leaf and stem tissues, increases in tissue longevity or increases in the water status of defoliated plants (Briske and Richards, 1995). Leaf replacement was rapid immediately after defoliation. However, it was not great enough as to allow leaf lengths to be either similar or greater on defoliated than on undefoliated plants in all genotypes during the first year (but in L. cinereus cv. 'Magnar').

Leaf lengths per unit basal area between both defoliation managements in all genotypes were similar immediately after defoliation in 2008/2009. Water stress conditions at this time (during November and December, when defoliation occurred, rainfall was 0.5 and $32.5 \mathrm{~mm}$ respectively, and potential evapotranspi- ration was 139.8 and $155.4 \mathrm{~mm}$ respectively) very likely constrained defoliated plants from growing faster than the undefoliated controls. The effect of water stress in constraining growth of defoliated plants has been observed in various perennial grasses (Busso et al., 1989, 2003).

Dry-matter production was similar in the native than in most of the introduced genotypes during both study years. During the second growing season, drymatter production was similar in the native and naturalized species, but greater in L. cinereus cv. 'Magnar' than in the native species. Defoliated plants of all genotypes showed a greater dry-matter production than the undefoliated ones during the first study year. This is an indication that defoliated plants tolerated defoliation. However, the dry 2008/2009 may have constrained defoliated plants from reaching a greater dry-matter production than their undefoliated counterparts. Mohammad et al. (1982) found that the amount of regrowth in Agropyron desertorum and Elymus junceus was inversely related to the increased water stress to which plants had been previously exposed. The low rainfall $(29.5 \mathrm{~mm}$, Figure 1) during the most active growth period (early to mid-spring: September to November) in 2008/2009 and the cumulative effects of two successive years of two severe defoliations annually (which determined substantial reductions in tiller numbers per plant, production of daughter tillers per square centimetre, total leaf length per square centimetre and plant survival) contributed to reductions in plant dry weight per square centimetre between the first and second years. The negative effects on plant growth of the combined influence of water stress periods and at least one severe defoliation during two or more consecutive years have been demonstrated in various perennial grass species from temperate regions (Busso et al., 1989, 2003). Like in our study, these research works indicated that the difference in plant responses between consecutive years can have great biological significance.

We have to highlight that the drier 2008/2009 than 2007/2008 conditioned plant responses to defoliation and increased difficulty in interpretation of results. It is well known that plant growth and survival, and tiller formation are very sensitive to water stress (Busso et al., 1989; Briske and Richards, 1995). The native and naturalized species and L. cinereus showed better performance than the remaining genotypes after defoliation under water stress in the growing season of 2008/2009. Blades of L. cinereus cV. 'Trailhead' which grew at the study site, for example, showed osmotic adjustment (Torres et al., 2010). This physiological mechanism allows plants to sustain leaf growth under severe water-stress conditions (Kirkham, 2005). Achanatherum hymenoides cvs. 'Nezpar' 
and 'Rimrock' showed an important leaf production (Torres, 2010), but they did not survive beyond the first study year.

Plant survival was greater in the native species than in the introduced genotypes. Similar results have been reported for other species in Pappophorum under grazing conditions (Privitello et al., 1998). Survival values shown by $L$. cinereus and $A$. hymenoides after 2 years of study were lower than those reported by other authors on different environmental conditions and defoliation managements (Tilley, 2005). However, several authors reported difficulties for plant establishment of $L$. cinereus and A. hymenoides in various semi-arid regions of the USA (Vogel and Jensen, 2001). In this study, plants were grown from seeds at the greenhouse, and seedlings were transplanted to plots on single rows of space-transplanted plants on $1 \cdot 1 \mathrm{~m}$ centres. Fernández et al. (1991) reported that failure of E. curvula introduction in the study region is due to its reduced seed size and low growth rates when precipitations are low.

Climate on semi-arid and arid areas has a great influence on plant populations not only because precipitation is low but also because its distribution during the growing season is unpredictable (Huxman et al., 2004). Plant establishment is often related to high precipitations during certain times, while plant mortality is correlated with extended low precipitation periods (Turner, 1990). Bleak et al. (1966) and Roundy (1985) have emphasized the high sensitivity of plant establishment to water stress of $L$. cinereus and A. hymenoides in areas receiving less than $200 \mathrm{~mm}$ annually. In 2008/2009, precipitations were $29.5 \mathrm{~mm}$ from September to November (the most active growing period), $92 \mathrm{~mm}$ from December to February and $10 \mathrm{~mm}$ from March to May.

We have to acknowledge a limitation in this study: the introduced genotypes are intended for grazing, but they were assessed under clipping. It is well known that clipping at a given height does not adequately mimic grazing. The primary reasons for this difference are that (i) grazing does not remove uniform amounts of forage from all tillers, hence tiller removal from plants is unrealistically severe, and (ii) grazing animals have substantial indirect effects such as soil compaction and recycling of nutrients via dung and urine (Asner et al., 2004). The greater production or growth on grazed than clipped plants has been partially attributed to the non-uniform nature of herbivory (Parsons et al., 1984).

We have to reject our hypothesis because daughtertiller production and the subsequent dry-matter production were most often similar or greater on the introduced than on the native genotype during the two study years. Plant survival at the end of the study, however, was greater in the native than in the introduced genotypes. Plant of these introduced genotypes showed a weakened stage into the second, dry year, leading to reduced growth variables, and a high plant mortality at the end of the study. As a result, further studies should focus on improving plant persistence of the introduced genotypes. There is a worldwide need for developing more appropriate forage resources for arid and semi-arid grasslands and rangelands (Torres, 2010).

\section{References}

Allen V.G., Batello C., Berretta E.J., Hodgson J., Kothmann M., Li X., Mcivor J., Milne J., Morris C., Peeters A., Sanderson M. (2011) An international terminology for grazing lands and grazing animals. Grass and Forage Science, 66, $2-28$.

ANDERSON D.L. (1980) The recuperation and improvement of rangelands. Ecología Argentina, 4, 9-11.

Asner G.P., Elmore A.J., Olander L.P., Martin R.E. and ThомAs HARris A. (2004) Grazing systems, ecosystem responses, and global change. Annual Review of Environment and Resources, 29, 261-299.

Becker G.F., Busso C.A., Montani T., Brevedan R.E., Orchansky A., Burgos M.A. and Flemmer A.C. (1997) Effects of defoliating Stipa tenuis and Piptochaetium napostaense at different phenological stages. II. Tiller demography and growth. Journal of Arid Environments, 35, 251-268.

Bleak A.T., Frischinecht N.C., Plummer A.P. and E ckert R.E. JR (1966) Problems in artificial and natural revegetation of the arid shadscale vegetation zone of Utah and Nevada. Journal of Range Management, 18, 59-65.

BRISKE D.D. and RichARDS J.H. (1995) Plant responses to defoliation: a physiological, morphological and demographic evaluation. In: Bedunah D.J. and Sosebee R.E. (eds) Wildland plants: physiological ecology and developmental morphology, pp. 635-710. Denver, CO, USA: Society for Range Management.

Busso C.A., Mueller R.J. and Richards J.H. (1989) Effects of drought and defoliation on bud viability in two caespitose grasses. Annals of Botany, 63, 477-485.

Busso C.A., Richards J.H. and Chatterton N.J. (1990) Nonstructural carbohydrates and spring regrowth of two cool-season grasses: interaction of drought and clipping. Journal of Range Management, 43, 336-343.

Busso C.A., Brevedan R.E., Flemmer A.C. and Bolletta A.I. (2003) Morphophysiological and demographic responses of perennial grasses to defoliation under water stress. In: Hemantaranjan A. (ed.) Plant physiology and plant molecular biology in the new millenium, pp. 341-395. Advances in Plant Physiology, Vol. V. Scientific Publishers, Jodhpur, India.

Busso C.A., Giorgetti H.D., Montenegro O.A. and Rodríguez G.D. (2004) Perennial grass species richness and diversity on Argentine rangelands recovering from 
disturbance. Phyton, International Journal of Experimental Botany, 53, 9-27.

Cabrera A.L. (1976) Phytogeographical regions in Argentina. In: Ferreira Sobral E.F. (ed.) Enciclopedia Argentina de Agricultura y Jardinería, pp. 1-85. ACME, Buenos Aires, Argentina.

C Ano E. (1988) Rangelands of the Province of La Pampa. Description of the most important species. AACREA Province of La Pampa, Buenos Aires, Argentina. 425 p.

Chambers J.C. and Miller J.R. (eds) (2004) Great Basin riparian ecosystems - ecology, management and restoration. Island Press, Covelo, CA. 303 p.

De Graaf M.C.C., Verbeek P.J.M., Bobbink R. and Roelofs J.G.M. (1998) Restoration of species-rich dry heaths: the importance of appropriate soil conditions. Acta Botanica Neerlandica, 47, 89-111.

Di Rienzo J.A., Casanoves F., Balzarini M.G., González L., Tablada M. and Robledo C.W. (2009) INFOSTAT. Grupo INFOSTAT, Faculty of Agropecuarian Sciences. Argentina: National University of Córdoba.

Distel R.A. and B óo R.M. (1996) Vegetation states and transitions in temperate semiarid rangelands of Argentina. In: West E.N. (ed.) Proceedings of the Vth International Rangeland Congress. Rangelands in a Sustainable Biosphere, pp. 117-118. Soc Range Manage, Salt Lake City, UT.

Fernández O.A. and Busso C.A. (1999) Arid and semiarid rangelands: two-thirds of Argentina. In: Arnalds O. and Archer S. (eds) Case studies of rangeland desertification, pp. 41-60, Agricultural Research Institute Report No 200, Reykjavik, Island.

Fernández O.A., Brevedan R.E. and Gargano A.O. (1991) Weeping lovegrass. Its Biology and Management. Argentina: CERZOS-National University of the South, Bahía Blanca, $381 \mathrm{p}$.

Flemmer A.C., Busso C.A. and Fernández O.A. (2002) Bud viability in perennial grasses: water stress and defoliation effects. Journal of Range Management, 55, $150-163$

Gior GetTi H.D. (ed.) (1995) Meeting of cattle raising in shrublands. Chacra Experimental de Patagones, Viedma, Argentina. 56 p.

Giorgetti H.D., Montenegro O.A., Rodríguez G.D., Busso C.A., Montani T., Burgos M.A., Flemmer A.C., Toribio M.B. and Horvitz S.S. (1995) Biomass of herbaceous species and its correlation with precipitation in the Phytogeographical Province of the Monte. XVII Argentinian Ecology Meeting, Mar del Plata, Buenos Aires, 24-28 April. pp. 166.

Giorgetti H.D., Montenegro O.A., Rodríguez G.D., Busso C.A., Montani T., Burgos M.A., Flemmer A.C., Toribio M.B. and Horvitz S.S. (1997) The comparative influence of past management and rainfall on range herbaceous standing crop in east-central Argentina: 14 years of observations. Journal of Arid Environments, 36, 623-637.

Giorgetti H.D., Manuel Z., Montenegro O.A., Rodríguez G.D. and Busso C.A. (2000) Phenology of some herbaceous and woody species in central, semiarid Argentina. Phyton, International Journal of Experimental Botany, 69, 91-108.

Giorgetti H.D., Busso C.A., Montenegro O.A., Rodríguez G.D. and Kugler N.M. (2006) Cattle raising in central, semiarid rangelands of Argentina. Rangelands, 28, 32-36.

HodGKinson K.C. (2010) Perennial grass survival in drought. In: EldridgeD.J. and Waters C. (eds) Proceedings of the 16th Biennial Conference of the Australian Rangeland Society, Bourke, Perth: Australian Rangeland Society. 7 p.

Huxman T.E., Snyder K.A., Tissue D., Leffler A.J., Ogle K., Pockman W.T., Sandquist D.R., Potts D.L. and S CHWinning S. (2004) Precipitation pulses and carbon fluxes in semiarid and arid ecosystems. Oecologia, 141, 254-268.

JACKSON R.B. and CALDWELL M.M. (1989) The timing and degree of root proliferation in fertile-soil microsites for three cold-desert perennials. Oecologia, 81, 149-153.

Johnson D.A., Asay K.H. and Jensen K.B. (2003) Carbon isotope discrimination and yield in 14 coolseason grasses. Journal of Range Management, 56, 654-659.

Jones T.A. (1990) A viewpoint on Indian ricegrass research: its present status and future prospects. Journal of Range Management, 43, 416-420.

Kirkham M.B. (2005) Principles of soil and plant water relations. San Diego, CA: Elsevier Academic Press. 500 p.

LARCHER W. (2003) Physiological plant ecology, 4th edn. Berlin, Germany: Springer-Verlag. 513 p.

MAJeRuS M.E. (1992) High-stature grasses for winter grazing. Journal of Soil and Water Conservation, 47, 224225.

Maron J.L., Vila M., Bommarco R., Elmendorf S and BeARdSLey P. (2004) Rapid evolution of an invasive plant. Ecological Monographs, 74, 261-280.

Mohammad N., Dwyer D.D. and Busby F.E. (1982) Responses of crested wheatgrass and russian wildrye to water stress and defoliation. Journal of Range Management, 35, 227-230.

Niu S., Liu W. and Wan S. (2008) Different growth responses of $\mathrm{C}_{3}$ and $\mathrm{C}_{4}$ grasses to seasonal water and nitrogen regimes and competition in a pot experiment. Journal of Experimental Botany, 59, 1431-1439.

Noy-MEIR I. (1973) Desert ecosystems: environment and producers. Annual Review of Ecology and Systematics, 4, $25-51$.

Ogle D.G., St. John L., Holzworth L., Winslow S.R. and Jones T.A. (2002) Basin wildrye, NRCS Plant Guide.USDA, NRCS, Idazo State Office and the National Plant Data Center, USA, 6 p.

Parsons A.J., Collet B. and Lewis J. (1984) Changes in the structure and physiology of a perennial ryegrass sward when released from a continuous stocking management: implication for the use of exclusion cages in continuously stocked swards. Grass and Forage Science, 39, $1-9$.

Privitello M.J.L., Gabutti E.G. and Harrison R.U. (1998) Effects of two intensities and four frequencies of defoliation on persistence and production of Pappophorum pappiferum (Lam.) O.K. Revista Argentina de Producción Animal, 18, 111-115. 
Richard S.H. and Caldwell M.M. (1985) Soluble carbohydrates, concurrent photosynthesis and efficiency in regrowth following defoliation: a field study with Agropyron species. Journal of Applied Ecology, 22, 907-920.

Roundy B.A. (1985) Emergence and establishment of basin wildrye and tall wheatgrass in relation to moisture and salinity. Journal of Range Management, 38, 126-131.

Ruiz M. and Terenti O. (2012) Germination of four grasses under salt stress. Phyton, International Journal of Experimental Botany, 81, 169-176.

Schacht W.H., Smart A.J., Anderson B.E., Moser L.E. and RAsB Y R. (1998) Growth responses of warmseason tallgrasses to dormant-season management. Journal of Range Management, 51, 442-446.

S OKAL R.R. and RohlF F.J. (1984) Introduction to Biostatistics. Publishing Reverté S.A., Barcelona, Spain, $376 \mathrm{p}$.

Tilley D.J. (2005) Basin wildrye, advanced evaluation. Preliminary Report,Aberdeen, Idaho: Natural Resources Conservation Service, USDA, Aberdeen Plant Materials Center. 2 p.

Torres Y.A. (2010) Morphophysiological characteristics and forage production on native, naturalised and introduced, warm-season perennial grasses in the Centre of Argentina. Thesis of Doctor in Agronomy, Bahía Blanca, Argentina: Universidad Nacional del Sur. 200 p.

Torres Y.A., Busso C.A., Montenegro O.A., Giorgetti H.D., Rodríguez G.D. and Bentivegna D.
(2010) Osmotic adjustment in Leymus cinereus cv. "Trailhead" under field conditions. Phyton, International Journal of Experimental Botany, 79, 195-198.

Torres Y.A., Busso C.A., Montenegro O.A., Ithurrart L., Giorgetti H., Rodriguez G., Bentivegna D., Brevedan R., Fernandez O.A., Mujica M.M., Baioni S., Entio J., Fioretti M. and TucAt G. (2011) Defoliation effects on the arbuscular mycorrhizas of ten perennial grass genotypes in arid Patagonia, Argentina. Applied Soil Ecology, 49, 208-214.

TURNER G.T. (1990) Long-term vegetation change at a fully protected Sonoran desert site. Ecology, 7, 464-477.

USD A, NRCS (2000) The PLANT database. Version 000417. Baton Rouge, Louisiana: National Plant Data Center. Available at: http://plant.usda.gov.

Vilá M. and Weiner J. (2004) Are invasive plant species better competitors than native plant species? - evidence from pair-wise experiments. Oikos, 105, 229-238.

Vogel K.P. and Jensen K.J. (2001) Adaptation of perennial triticeae to the eastern Central Great Plains. Journal of Range Management, 54, 674-679.

WILKS S.S. (1932) Certain generalizations in the analysis of the variance. Biometrika, 24, 471-494.

Wilsey B.J. and Polley H.W. (2006) Aboveground productivity and root-shoot allocation differ between native and introduced grass species. Oecología, 150, 300-309. 